\title{
Vprašanje vere in dvoma pri slovenskih protestantih (primer Primož Trubar)
}

\author{
Alenka Jensterle Doležal \\ Univerzita Karlova v Praze, Filozofická fakulta, Nám. Jana Palacha 2, \\ CZ-11638Praha1,dolezalova.l@volny.cz
}

\section{SCN I/1 [2008], 28-41}

$\mathrm{V}$ prispevku je analizirano vprašanje vere in dvoma $\mathrm{v}$ dveh delih Primoža Trubarja: v delu Ena dolga Predguvor (1557) in Cerkovna ordninga (1564). Vera je v Trubarjevem razumevanju vrojena, dar božji in izhaja iz interpretacije biblije. Vero dojema kot osnovni religiozni in moralni fenomen, ki razkriva tako problem človekovega odnosa do boga kot tudi do skupnosti, njegove moralne in verske vpetosti v socialni in zgodovinski kontekst. Tako pojmovanje kategorizira dvojnost sveta: pravo vero in svet pravih vernikov na eni strani, na drugi nepravo vero, dvom, nerazumevanje in laž, skupnost ljudi, ki živijo v zmoti. Dvom spada v območje greha, je odklon od božjega zaupanja in neupoštevanje božje avtoritete.

This article analyzes the phenomenon of faith and doubt in two works of the Slovene protestant author Primož Trubar, the greatest Slovenian author of the 16 $6^{\text {th }}$ century: Ena dolga predguvor (1557) and Cerkovna ordninga (1564). In Trubar's interpretation, faith is inherited; he understands it as a gift from God. The meaning of faith is focused through interpretation of the Bible. Faith is the main religious and ethical phenomenon; it presents man's relation not only to God but also to society, and his relationship to existential, social, and moral reality. In Trubar's, view the world is dual: it is divided into society with the right faith, and the condemned one, the society of others who live a lie, who don't have the right faith. Doubt is the space of sin; it is the space without God's mercy.

Ključne besede: književnost Primoža Trubarja, vprašanje vere v Trubarjevem literarnem delu, slovenski protestantizem

Key words: The literature of Primož Trubar, the question of faith in Trubar's literal work, Slovene reformation 
Letu je nom sam Jezus s sujo martro dobil inu je nom tu istu zabston dal tar šenkal, inu tako šenkingo mi skuzi to vero $v$ nega nase perpravimo. Zakaj ta vera je ta prava mošna inu skrina, kir tak božji dar, tu zaslužene Kristusevu inu nega pravico prejme, vzame, shrani inu zaklene, kateri ima tiga Sinu (zastopi skuzi to vero), ta ima ta večni leben. (Trubar, Catechismus, 1550, I sl.)

V svojem prispevku se bom ukvarjala s problemom vere pri Primožu Trubarju in glede na to, da je bila vera esencialna kategorija v njegovem teološkem sistemu, bom poudarila nekatera semantična vozlišča njegove teološke in filozofske misli. Primož Trubar ni samo začetnik slovenske književnosti in slovenskega jezika, ampak tudi mislec, vizionar, teolog in tudi politik. Hotela sem premisliti glavne postulate vere $\mathrm{v}$ dveh njegovih tekstih in ju analizirati glede na dani problem. Pri tem sem izhajala ne samo iz sekundarne literature, amak predvsem iz pozornega branja in interpretiranja tekstov. S tem sem hotela izkazati tudi spoštovanje veliki osebnosti, kot je bil Primož Trubar: interpretacija religioznih tekstov je bila tudi zanj ključna za razumevanje in posredovanje vere, v svojem protestantskem poslanstvu učitelja in duhovnika se je čutil dolžan, da predvsem interpretira Sveto pismo in ga posreduje dalje imaginarni skupnosti vernikov. Trubar je kot protestant izhajal iz prepričanja o človekovi osebni, notranji veri. Biblija je bila zanj vir verskega spoznanja, ki jo je sprejemal vernik prav z branjem in s pisanjem v slovenskem jeziku. Jože Koruza je leta 1983 v članku o slovenskem protestantizmu (Koruza 1983: 16) izpostavil Trubarjevo misel, da že osnovno obvladanje katekizma omogoča pravo razumevanje biblije, branje pa je temeljni vir prave in žive vere, kar je bilo v protestantskem okviru samo po sebi razumljivo. Teolog Vekoslav Grmič je v raziskovanju Trubarjeve teološke misli leta 1986 zapisal, da je imel Trubar pod vplivom humanizma naravnost religiozen odnos do jezika in do pisanja $\mathrm{v}$ maternem jeziku in tega naj bi se navzel $\mathrm{v}$ Trstu in morda tudi na Dunaju (Grmič 1986: 133).

Za svojo raziskavo sem izbrala dve značilni deli iz njegovega opusa: Eno dolgo predguvor iz leta 1557 (v obsežnem delu Ta pervi dejl tiga novega testamenta), izdano v Urachu, in Cerkovno ordningo iz leta 1564 (Slowenische Kirchenordnung), izdano v Tübingenu. V svojem razmišljanju se poskušam navezati tudi na tradicijo znanstvenikov slovenistov na Češkem. Prav Matija Murko je leta 1927 v članku o reformaciji in protireformaciji izrazil prepričanje, da lahko odkrivamo Trubarjevo teološko miselnost prej v slovenskih kot v nemškem predgovorih. Vprašanje avtorjeve izvirnosti v njegovem teološkem prepričanju bo ostalo na obrobju naših analiz, kljub temu da vemo, da se Ena dolga predguvor nanaša na Bullingerja in njegov predgovor k Janezovemu evangeliju iz leta 1556 in na Melanchtonovo knjigo Loci theologici; Cerkovna ordninga je bila spet svobodna predelava würtemberškega cerkvenega reda, ${ }^{1}$ saj je to preveč kompleksen problem, s katerim so se ukvarjali že drugi.

${ }^{1}$ Jože Rajhman pri problemu izvirnosti poudari tudi posebno pojmovanje avtorstva v 16. stoletju, kjer je navezovanje na tuje avtorje Trubarju omogočalo tudi neke vrste mimi- 
Kot ugotavlja Jože Rajhman, se pri Trubarju problem vere pojavlja že v prvem Katekizmu, kjer zapiše znamenito pridigo o veri, ki naj bi jo tudi večkrat ponovil: vera je »dar božji«, je darovana: »ana šenkiga«. Vera je vrojena, podedovana, človek jo ima ali pa je nima, je božji dar in če parafraziramo, je vrojena, podobno, kot je vrojen tudi izvirni (dedični) greh. Kljub temu, da je vera človeku dana apriori, Trubar predpostavlja, da se mora človek tudi potruditi, da se vera v njem zakorenini, zato na koncu te pridige v Katekizmu opomni poslušalce, da je treba upoštevati zakramente, zapovedi, moliti - in spoštovati verske zakonitosti ter cerkveni red. Za božjo milost in prostor vere pa se je treba truditi tudi s poštenim življenjem - vera predpostavlja vprašanje človekove moralne odločitve in ravnanja v obredju človekove kontinuitete ali kot pravi Trubar svojim vernikom: »inu pelajte an pošten leben«. Jože Rajhman tudi konstatira, da ima Trubarjeva vera, ki je vera v Kristusa, leta 1557, ko je pisal teološki traktat Ena dolga predguvor, kot pred sedmimi leti, dva dela: sprejem razodetja in zaupanje (Rajhman 1986: 92). Vera v Eni dolgi predguvori je po Rajhmanovem mnenju nadaljnja razvojna stopnja, to naj bi bilo spoznanje o veri, ki se izoblikuje v pojem »sola fide« (Rajhman 1986: 90, 91, 92).

Trubarjeva Ena dolga predguvor ${ }^{2}$ je izšla leta 1557 v obsežnem delu Ta pervi dejl tiga novega testamenta in ima po Ruplu 196 strani. Razprava je razčlenjena na pet delov in več pomensko sklenjenih poglavij. Teološki traktat, kot ga Rajhman (1986: 5) tudi poimenuje, ima predgovor, ki ga je Trubar poimenoval Ta kratka predguvor in Regišter te predguvori. Predgovor razlaga namen razprave, register semantično selekcionira glavne misli in jih strukturira $\mathrm{v}$ poglavja. Vprašanje vere je za Trubarja vprašanje božjega in v zgodovinskem kontekstu predpostavlja območje pravih vernikov, skupnost, občestvo tistih, ki verjamejo v pravega boga in nosijo v sebi pravo vero. Na drugi strani so tisti, ki nimajo niti prave vere niti pravega boga, na primer Turki. V poročilu Trubar kot enega glavnih motivov za nastanek Ene dolge predguvori navaja spreobrnitev Turkov, ki naj bi spoznali, da je prava vera le krščanska, mohamedanska pa kriva. Leta 1557 je še zagovarjal misel, da naj bi knjiga v hrvaškem in slovenskem jeziku pomagala njegovim rojakom v borbi proti Turkom (Rajhman 1986: 8), nekaj let kasneje je začel poudarjati mesijansko nalogo protestantske

krijo, skrivanje lastnih idej, ki jih v tem času ni smel čisto odkrito zapisati: »Trubar se je rad skliceval na priznane avtorje. To je bilo potrebno za njegovo delo, kajti nakopal bi si še večje nevšečnosti, njemu pa ni bilo toliko do priznanja avtorstva kolikor do tega, da je dosegel potrditev slovenskih spisov pri višji instanci. Pod tujim imenom je vnašal v svoje knjige lastne poglede in jih na ta način obvaroval pred proskripcijo« (Rajhman 1977: 8).

2 Trubar, Primož, 1557: Ena dolga predguvor k novemu testamentu, Reprint Cankarjeva založba v Ljubljani, 1986. 
knjige, ki naj bi spreobrnila neverne Turke. Prav njegova dejanja dokazujejo tudi določeno mero strpnosti do drugih verstev: drugo vero je dojemal tudi kot duhovni izziv in drugačno teološko miselnost; Jože Pogačnik piše, da je leta 1567 skrivaj prišel v slovenske dežele in se je poizkušal povezati z ujetimi Turki v Ljubljani in Ribnici (Pogačnik 1973: 58).

Vprašanje vere je za Trubarja vprašanje Boga in človekovega odnosa do njega; Trubar nikoli ne dvomi, krščansko strukturo dojema v strogo zamejenih kategorijah, podobno kot je njegov teološki svet antinomično, strogo dualistično razcepljen na prostor prave vere, božjega, zveličanja, odpuščanja, večnega življenja na eni strani, na drugi pa prostor peklenskega, pogube, hudiča, greha. Trubar te svoje miselne vzorce - mišljenje $\mathrm{v}$ nasprotjih $\mathrm{v}$ predgovoru poimenuje kot konflikt, razcepljenost med Božjo milostjo, svetimi nebesi in peklom, hudičevo oblastjo. Obenem je tudi prepričan v dualistično razcepljenost družbe, to je zanj tako sociološko in zgodovinsko dejstvo kot tudi moralna danost, ki je spet osnovana na vprašanju sprejetja in razumevanja prave vere, ki pa je samo protestantska: dvomijo, so zaslepljeni, ne verujejo ti drugi, neverniki, drugoverni, grešniki, ki se ne obnašajo bogu primerno.

Prvo področje, ki morda implicira tudi vprašanje dvoma, je prostor greha in temu posveča več poglavij: 25. in 28. poglavje. V 28. poglavju razlikuje $d v e$ vrsti greha: porodni, erbovni - izvirni greh, iz katerega pa rastejo in pridejo po Trubarjevih besedah drugi grehi: storjeni, doperneseni, poimenovani tudi notranji grehi. Storjeni grehi so grehi, ki jih naredi človek, ko misli: misli, želi, govori in stori zoper božjo voljo in zoper njegovo zapoved in tu se pojavi prvi stavek o dvomu:

Ti noterni grehi, kir se s tem sercem inu s to mislijo sture, so tu zbiulane na božjih besedah, kir tim božim oblubam inu pritežom cilu, terdno, stanovito inu popolnoma ne veruiemo, se ne veselimo na nega oblubah inu milosti, pred nega serdom inu pritešom se ne prestrašimo, nega ne lubimo iz celega serca, ne smo s celo dobro volo Bogu pokorni, v teh nadlugah inu v tim terplenu smo neuulní, kar bogu dopade inu hoče imeiti od nas tiga radi ne deimo, ampag kar našimu mesu inu životu dobro dei, htimo smo veseli, uolni inu pernaredni.

Dvom spada v območje greha, je odklon od božjega zaupanja, nevera v božjo miselnost in ljubezen, je stanje nezaupanja do boga, prevelike človekove egocentričnosti in samozavesti, tudi nepokornosti, neupoštevanja božje avtoritete. Za Trubarja je bilo to tako osebno vprašanje, a tudi vprašanje vseh, zato v tem primeru uporablja gramatično obliko mi: v skupnosti ljudi, ki včasih dvomijo, zaobseže tudi lastno osebo.

Morda se prav v 7. poglavju, ko Trubar poskuša osmisliti in razumeti smisel trpljenja, razpira v ozadju skriti dvom (Rajhman 1986: 19). Verjame, da je trpljenje na svetu od začetka, odkar je bog oznanil, da bo kača »njeno peto zalezovala « - za gorje na svetu je kriv hudobni duh. Tako kot je Kristus moral trpeti in umreti zaradi hudobnega duha in je trpel za vse ljudi, tako da je daroval celo svoje življenje, morajo tudi verniki več kot drugi ljudje trpeti. V 59. poglavju nasprotno razpravlja o vzrokih trpljenja. Kako usodno mu je 
bilo vprašanje trpljenja, vidimo po tem, da na vprašanje, zakaj morajo trpeti tudi pravični, Trubar navaja celo devet vzrokov.

Trubar trdno verjame $\mathrm{v}$ zakodirano metafizično krščansko topografijo, mitos, ki je strukturiran $\mathrm{v}$ jasen sistem. Na vrhu transcendentalnega trikotnika stoji bog, ki se bliža ljudem z milostjo in ljubeznijo, a tudi s pravičnimi in strašnimi kaznimi za grešnike. Molitev, pridiga in postava pa nasprotno boga približujejo ljudem. V tem je prisotna tudi krščanska eshatologija, obljuba prihodnosti večnega življenja, kot pravi Trubar, »večnega lebna«, in prav na to krščansko eshatološko perspektivo prihodnosti v svojih interpretacijah opozarja od vsega začetka (že v slovenski naslovnici Katehizma ima slovensko varianto naslova: »Anu kratku podvučene, s katerim vsaki človek more v nebo priti«) (Berčič 1968: 168). V eshatološki časovni verigi prava vera predpostavlja tudi razumevanje in obujanje preteklosti, tako krščanske zgodbe o stvarjenju sveta in nadaljevanju: stvarjenju človeka po božji podobi, a tudi o Adamu in Evi kot prvih ljudeh, ki sta storila greh (tej razlagi bistvenega trenutka iz človeške zgodovine Trubar posveti več poglavij). Osnovna - substancialna zgodba iz krščanskega mita je zgodba o Jezusu Kristusu, ki je trpel in na križu daroval svoje življenje za ljudi, zato Primož Trubar kot razlagalec vere in posrednik vseskozi ponavlja zgodbo o svetem življenju in smrti Jezusa Kristusa kot mitičnem začetku, njegovo trpljenje in smrt kot darovanje in kot pogoj za odrešenje vseh.

$\mathrm{V}$ razumevanju vere obstaja teološka in moralna razdelitev sveta na dobro in zlo. Trubarjeva teološka misel predpostavlja drugega, sovražnika, svet hudiča in zlodejev, območje peklenskega, območje tistih, ki imajo krivo vero (Turki in Judje), ali pa sploh te vere nimajo (ajdi - pogani). Obstajajo tudi drugi nepravi »falš« kristjani, ki so sicer to vrojeno vero imeli, a tega razodetja vere niso ohranili in se niso trudili spoznati prave vere v svojem življenju. Ti s svojimi dejanji žalijo boga in so prekleti, bog jih kaznuje že v sedanjosti. Ti brez vere grešijo, izpostavljajo se celo smrti in jih bo bog že v tem življenju kaznoval. Sodniško vlogo boga ekspresivno poudari v 30. poglavju Te kratke predguvori, kjer s ponavljanjem in nazornimi, čustvenimi primerami poskuša v poslušalcu vzbuditi vse grozote pogubljenja in božjega srda zaradi grešnikov. Prav ti nimajo nikakršne obljube večnega življenja - čeprav tudi tu ponavlja, da je bog predvsem milost in da je Jezus Kristus s svojim velikim trpljenjem in smrtjo dosegel odpuščanje vseh grehov. A tu spet zapiše paradoks Kristusovega konca: tudi on je pred smrtjo na križu v največjem trpljenju zavpil: »O bog, zakaj si me ti zapustil«.

Trubar v 12. poglavju zatrdi, da je bila vedno samo ena prava vera: »inu ta bode do konca sveta«. Prav v tem poglavju zapiše metaforo, da je vera kot ena gospa ali kraljica, služabniki in dekle se menjajo - vera ostaja do konca.

Nerazumevanje vere se izraža v žrtvovanju in malikovanju in o tem govori v 10. poglavju Ene dolge predguvori. Neverni so ajdi in Judi. Trubar opisuje razloge in vzvode darovanja ter žrtvovanja po svetopisemskem izročilu, ki se je kasneje razvilo kot negativna dejavnost, kot šega in navada, ki so jo prevzeli neverni, nepravoverni. Področje drugega, nevernika, sovražnika Trubar spet opisuje zelo ekspresivno, čustveno, literarne primere njihovega nekrščanskega 
žrtvovanja opremi in jih stopnjuje s srednjeveškimi podobami pekelnega: »su čestu v nih velikih nadlugah, v pomorih, vojskah in lakotah, - ne samo živino, ampak tudi žive ljudi žrtvovali«. Hudi, neverni ljudje naj bi celo lastne otroke žrtvovali. In ko »to žive judi in nedolžne otroke morijo, kolnejo inu žgo, je ena grozotna reč slišati«. Edina prava žrtev je po Trubarju Jezusova: njegovo trpljenje, smrt in žrtev.

V 13. poglavju obravnava Turke in Jude, ki trdijo, da je prav njihova vera prava in najstarejša, a so zanj izgubljeni, saj nimajo Kristusove vere, zato Judje niso Abrahamovi otroci in strici, kot oni pogosto trdijo, in tudi Turki ne izhajajo iz Sare, Abrahamove žene (zato naj bi se imenovali Saraceni), ampak so »Zlodeja sinovi« (hudičevi sinovi); pripisuje jim posebno krutost in pri tem izrazi celo občutek osebne ogroženosti: »saj vi hočete mene umoriti«, to pa ne bi delali Abrahamovi sinovi. Turška in judovska vera po njegovem mnenju nimata nobene osnove: nimata grunta, teološko vprašanje - sprejetje vere ima moralno, etično vrednost in to je vprašanje pravega ali napačnega razumevanja sveta, pravega in napačnega razumevanja svetega pisma, saj, kot trdi Trubar, če bi ti Judje razumeli sveto pismo, bi prestopili v »našo vero«. V 14. poglavju zapiše stavek, da se Judje in Turki naši veri posmehujejo.

Vendar Trubar ni napolnjen s sovraštvom do drugih in vsem prizna možnost odločanja, morda svobodne volje v moralnih odločitvah; v 17. poglavju tako zapiše, da so ajdi - pogani, neverniki, tudi če nimajo svetega duha, sposobni zadržati svoj srd, da ne ubijajo, »da ne bi komu sile inu krivu sturili, da ne bi krali, lagali in prešuštovali«. To misel celo dvakrat ponovi.

V naslednjih poglavjih se ukvarja s kristjani, ki so izgubili vero, ki si ne prizadevajo za vero, nimajo vere v Kristusa, ki grešijo v vseh možnih oblikah; to poudari ekspresivno in tudi večkrat ponovi, kakšni so ti grehi. Zlodej - Hudič tako vernike odvrača od te vere, ali kot piše Trubar v 28. poglavju: »da malikujejo, krivo prisegajo, krivo pridigajo inu vuče, to prepovedane od Boga inu falš Božje Službe gori narejejo inu perpravjo, de rezijajo, kurbajo, kradejo, punte inu smešnaute vmej ludmi seženo, falš persegajo, inu druga grozoita dela zludjeja doperneso«. Tudi v 29. poglavju se ukvarja s temi, ki nimajo v sebi boga: to so tisti, »ki také (bogu nenaklonjene, op. A. J. D.) reči delajo in ti ne bodo erbici (dediči) tega božjega kraljevstva«.

Drugi del predgovora $\mathrm{v}$ 15. poglavju Trubar začenja prav z razlago troedinosti Boga: bog je en sam, a v troedinem bogu so skrite tri osebe, »persone«, tri imena: bog oče, bog sin in bog sveti duh.

$\mathrm{V}$ razumevanju vere posega tudi v bolj abstraktne ravni, metafizične sfere. Pri tem noče govoriti v svojem imenu, ampak se sklicuje na učenjake. V 17. poglavju razmišlja, da je bil človek ustvarjen po božji podobi (božjem pildu), zato so v njem moči božje duše: zastopnost - razum (kot odraz božje modrosti), pumnene - spomin (odraz božje moči), volja (odraz božje pravice). V tem poglavju Trubar zagovarja trditev, da boga spoznamo po človeku, ki je božja podoba.

Sprejetje vere je po Trubarju razumevenje duhovnega principa, ideje božje, saj kot pravi v istem poglavju, bog nima telesne oblike, nima obraza in obličja, je samo duhovna substanca: pri tem se sklicuje na biblijo. Opiše ga z ekspresiv- 
nimi pridevniki, že literarnimi atributi: »Bog /.../ je en Duh, ena večna, živa, samostoječa, modra, vsigamogočna, nevideča, neizrečena, dobra, pravična, sveta, risnična, zvivolna inu čista misel.« $\mathrm{V}$ istem poglavju tudi poudari njegovo stvariteljsko vlogo pri nastanku sveta. Vloga demiurga se povezuje z resnico.

Vera je tudi določen način razumevanja sveta, ki temelji na posebni percepciji. O tem govori še posebno v 37. poglavju, ko zapiše pojmovanje vere: ko verujemo, vidimo »s tejmi notermi očima: nevidljive stvari, ker nam jih božji duh razodeva po svetem pismu. Neverni te sposobnosti nimajo."

Primož Trubar v tem delu tematizira vprašanje vere in nevere tako kot osebni, notranji problem, kot ekistencialno vprašanje $\mathrm{v}$ sistemu teoloških vrednot, človekovo vero išče v njegovem načinu razumevanja, $v$ njegovem razmerju do boga, to razmerje pa predpostavlja tudi razmerje boga do človeka, vera je način komunikacije na najbolj osebni ravni. Na obrobju poskuša interpretirati tudi bolj abstraktne kategorije vere, metafizična vprašanja, kot je vprašanje boga, njegove troedninosti, dojemanja in razodetja boga in smisla vere.

Vera je tudi problem verske skupnosti na eni strani; verski sistem vrednot tako predstavi kot spoznavni - aideloški in tudi moralni problem. Iz tega $\mathrm{v}$ njegovem sistemu izhaja zgodovinski in socialni antagonizem pravih in nepravnih vernikov.

$\mathrm{V}$ prvem cerkvenem redu $\mathrm{v}$ slovenskem jeziku (Cerkovna ordninga iz $1564)^{3}$ je Primož Trubar poskušal zapisati tako organizacijo slovenske cerkve, hkrati pa lahko cerkveni red jemljemo kot prvi pravni tekst $\mathrm{v}$ slovenskem jeziku. Znanstveniki ugotavljajo, da je Trubar delno sledil würtemberškemu cerkvenemu redu, vendar je bil pri tem dokaj samostojen. Primož Trubar je bil leta $1560 \mathrm{z}$ državnimi stanovi poklican, da se vrne v domovino kot predikant in superintendant. Knjiga je bila trinajsta $\mathrm{v}$ vrsti vseh slovenskih tiskov in po Trubarjevem predlogu natisnjena v Tübingenu v 400 izvodih in v septembru ter oktobru 1564 poslana na Kranjsko. Nadvojvoda Karel II. kot vladar notranjeavstrijskih dežel je bil protiprotestantsko razpoložen in je to dojemal kot poseg v svoje deželnoknjižne pravice in je spis prepovedal. Leta 1564 je bil Trubar prav zaradi cerkvenega reda že drugič in dokončno izgnan iz dežele.

Cerkovna Ordninga je zastavljena v obliki vprašanj in odgovorov, ki se dotikajo ključnih tem (tovrstna odločitev je bila v metodološkem pogledu za Trubarja kot pridigarja in učitelja pedagoško že preizkušena: že mali katekizem pri abecedniku je zapisal v obliki vprašanj in odgovorov med očetom in sinom). Delo se veže na socialni in zgodovinski kontekst, v svoji intencionalnosti je glede na prejšnje obravnavano delo veliko bolj realno, Trubar sledi

${ }^{3}$ Trubar, Primož, 1564: Cerkovna ordninga, Slowenische Kirchenordnung. Tübingen, reprint dr. Rudolf Trofenik, München, 1973. Trubar, Primož, 1975: Slovenska cerkovna ordninga. Ljubljana: Mladinska knjiga. 
določenemu realnemu cilju, tudi ko razmišlja o vprašanju vere; vero v okviru cerkvenega sistema dojema bolj praktično. $V$ delu opiše način cerkvenega življenja in molitve $\mathrm{v}$ vsakdanjem življenju in med prazniki. $\mathrm{V}$ tej odločitvi se skriva tudi vprašanje naslovnika; Trubar hoče biti jasen, dojemljiv za široke ljudske množice, predvsem hoče poučiti mlade in preproste ljudi, v posameznih odsekih poudarja pedagoški in moralni značaj dela. Na začetku opredeli, zakaj razdelitev na tri dele: »da se ta cela Božja beseda, tu je, ta postava, te zapuvedi inu ti evangeliji tim ljudem $v$ ti cerkvi očitu, prou inu zastopnu pridiguje, da se ti zakramenti, ta s. kerst, ta s. večeria Kristusova, prou dile inu jemio. Inu da se tu pravu pridiganje, ta velika šaca, derži inu ohrani, po vsem keršanstvu«. Prvi del pomeni zgoščeni povzetek verskega nauka, drugi del je svobodni prevod Examen ordinandum Philippa Melanchtona, namenjen predvsem novim pridigarjem (za njihovo eksaminacijo in potrditev). Tretji del je liturgičnega značaja in je tudi najdaljši - obsega kar 175 strani. Poglavitna tuja predloga je bil würtemberški cerkveni red. ${ }^{4}$

Primož Trubar je tudi v tem primeru dosleden, absolutno verujoč in sprejemajoč protestantsko vero, ko hoče zapisati sistem protestantske cerkve v diahroničnem in tudi sinhroničnem pogledu - ne samo kot normo in dogmo, ampak kot živo teološko misel. Vprašanje vere je predvsem vprašanje boga, ki ga spet večkrat opiše $\mathrm{z}$ atributi: bog je moder, pravičen, dober, resničen, pravičen in čist (prav tam: 10), pojavlja se tudi pesniški atribut svetel, čeprav opozarja, da je bog tudi neusmiljen sodnik, saj lahko tudi kaznuje - grešnike. Prav tako tu vprašanje vere ni samo vprašanje človekovega odnosa do boga, ampak se še bolj dotika posvetnih stvari, še posebno, ker Trubar v interpretaciji človeške realnosti v odnosu do boga izhaja iz konkretne zgodovinske in kulturne danosti, še bolj kot iz že omenjenih predhodnih zapisov. Cerkovna ordninga je zato tudi do določene mere antropološki tekst o stanju slovenske intelektualne misli v 16. stoletju, hkrati pa tudi vir etnoloških informacij. Rudolf Trofenik (1973: 12) tako zapiše, da je Cerkovna ordninga: »prvi tiskani slovenski pravni spomenik, ki ureja osnovna vprašanja cerkvene organizacije, bogoslužja in šolstva, krščevanja, poroke in pogreba«. Predvsem pa je politično dejanje, s katerim je želel Trubar vzpostaviti samostojno slovensko cerkev in ji določiti notranjo ureditev (Vinkler 2006: 96). Vera se tu še v večji meri razume kot kategorija, ki razkriva problem človekovega odnosa do kolektiva, njegove moralne in verske vpetosti v socialni ter zgodovinski kontekst. Poudari še pomen pravega kolektiva; v priznavanju skupnosti pravih - protestantskih vernikov je Trubar dogmatičen in izključujoč ter zagovarja absolutne kategorije in absolutni sistem. Zanima ga fenomen prave protestantske cerkve, ukvarja se z zgodovinskimi formami in normami prave protestantske Cerkve, katere pravila in predpisi so zavezujoči za vse. Verjame v edino pravo protestantsko Cerkev, označi jo celo za večno Cerkev, v kateri se mora širiti božja beseda preko protestantskih du-

\footnotetext{
${ }^{4}$ Kot poudarja Jonatan Vinkler, je tako podlaga za liturgijo slovenske protestantske cerkve postalo po vzoru srednjeveške pridigarske zasnovano preprosto obredje, kot se je najprej uveljavilo v reformirani Švici (Vinkler 2006: 98).
} 
hovnikov. Njihovo mesto je zavezujoče, vodila naj bi jih pokora in občutek za mesto v sistemu, v povezovalni razpetosti med bogom in skupnostjo vernikov, v Hermesovi vlogi med vednostjo in nevednostjo, božjim in zemeljskim. Tu spet uporabi znano svetopisemsko metaforo, pridigarji so služabniki božji, pod delo se podpiše kot božji pastir. Primož Trubar tudi tu izraža veliko spoštovanje in strah pred edinim bogom. Ne samo vprašanje vere, vključitev v protestantsko cerkev celo postavi kot pogoj človekovega odrešenja. Na tretji strani knjige zapiše, da človek, ki hoče biti zveličan, mora biti od prave cerkve, njen tovariš.

Formalno zagovarja in opredeljuje zavezujoči, a priori določeni sistem protestantske vere, njene zapovedi in postave. Vera je poudarjena kot poslanstvo, pridigarji naj bi imeli kot svoje poslanstvo to vero širiti, predvsem »med mlade in preproste ljudi«. Ko raziskujemo problem vere in dvoma v Cerkovni ordningi ugotavljamo, da tudi tu Primož Trubar ne dvomi, dvom je na strani tistih na drugi strani, ki ne zagovarjajo protestantskega nauka. Namerno poudarja tradicionalne sintagme in primere: pridigarja klasično metaforično primerja s pastirjem, verniki so ovčice. Nasprotno pa so vsi drugi izven; že v prvem poglavju govori o: »Obtu ti ajdi, turki, judi, papežniki, kir ta sveti evangelij, to čisto besedo božjo, souražjo, po nim ne verujo, Bogu ne služjo, ne so ta Cerkev Božja, ne so izvoleni ludi boži, temuč tega hudiča inu antikrista« (prav tam: 3).

Glavne postulate vere Trubar razloži v prvem pomenskem razdelku Od tiga navuka. Tudi tu sledi podobnemu loku misli kot v Predguvoru, sicer ne tako obširno in poglobljeno, interpretira zgodbo o stvarjenju sveta. Greh Adama in Eve interpretira kot padec, tragedijo »ženskega semena«. Več poglavij posveti tudi grehu, ki ga spet razdeli na porodni, erbovni - od Eve podedovani greh in pa notranji greh. V poglavju o grehu in grešnikih se posveti podobam pekla, kjer z ekspresivnimi izrazi in s sanjsko, iracionalno izrazitostjo podob skuša vplivati na poslušalce, da ne bo treba v peklu: »v trepetanju, v žalosti, v škripanju tih zob, $v$ tem večnim ognju, sideti inu terpeti« (prav tam: 10).

Zavest skupnosti je Trubar usvojil že zelo zgodaj. Jože Koruza ugotavlja, da je že v prvem poskusu bibličnega prevoda govoril ne več vernikom kot posameznikom, marveč verski skupnosti (Koruza 1983: 21), da govori o tej »pravi Cerkvi božji tiga slovenskega jezika« (Rupel 1966: 64).

Območje sovražnika - drugega, tistega, ki ne sprejema prave vere, tu še razširi. Med sovražne druge se poleg Turkov, ajdov, Judov, tistih, ki grešijo, tistih, ki Evangelij slabo razumejo ali ne verujejo, uvrstijo tudi papeški verniki, katoliki ali - kot jih poimenuje on - papežniki. Zato tudi govori proti papeški cerkvi in katolištvu, proti tako imenovanim papežnikom. Na strani katoliške cerkve pravi, da obstaja dosti krivega, nepravega in malikovalskega, v katoliški cerkvi zanj obstaja malikovalska, neprava božja služba in ljudje bi morali bežati pred malikovanjem. Ekspresivno papežnike imenuje tudi hudiči. V poglavju Kaj loči pravi krščanski nauk od judovskega, ajdovskega - poganskega, turškega in nepravega - falš keršanskiga nauka in od nih vere zelo čustveno naslika njihovo pogubo:

Ta šadašni judovski, ajdovski inu falš keršanski inu kezarski uk oli nauk, je zgul enu grzotnu, prekletu, ferdamnsku malikovanje, inu nih uk drugo ništer nei, samuc 
en majhen deiloli štuk od te postave, inu od te vunane človeške brume, inu od tega poštena. Zakaj leti ludii, ništer ne veido inu ne zastopjo, od tiga svetiga evngelija, od oblube božje, od božje milosti, odpuščane teh grehou, za volo Jezusa Kristusa. Inu kadar oni od tiga Božjega Sina Jezusa ne veido, ne znajo, ga ne česte, ne zastopie, du je on, zakaj je čloik ratal, se pustil martrati, umoriti, inu zakaj je ustal od smrti (prav tam: 4-5).

Vprašanje vere je vprašanje razumevanja in resnice, je sledenje etičnemu principu bivanja, a na strani nevere Trubar odkriva laži in zaslepljenosti: taki ljudje so od boga zavrženi in bodo kaznovani. Njihovo dejanje Trubar označi kot »malikovanje in pregreho«. Nasploh častijo drugega boga, molijo k drugemu bogu, ki pa ni bog. Trubar pri dojemanju prave vere spet poudarja razumevanje in spoznanje.

$\mathrm{V}$ več razdelkih tudi razpravlja, kako loči pravi krščanski nauk od judovskega, ajdovskega, turškega in »falš kerščanskega vuka« in od njih vere. V tem smislu pravi, da ne časte pravega boga in ne razumejo nauka, da je Jezus Kristus umrl za vse ljudi. Častjo drugega boga, ki ni bog.

$\mathrm{V}$ razdelku Od tiga navuka posveti največ poglavij razliki med protestantsko in katoliško vero: »Kaj loči ta naš pravi evangelijski nauk v letim articuli od tiga kriviga papežoviga nauka« (prav tam: 21).

V odgovoru na vprašanje ugotavlja tri stvari: pravi vernik - človek z dobrimi deli zasluži odpuščanje teh grehov in nebesa. V katoliškem obredju dobijo zveličanje pretežno z mašami in meništvom. Papeški verniki po njegovem ne verjamejo, da je človek lahko rojen drugič skozi evanglije in svetega duha; ne verjamejo, da jih bog sprejema. Po Trubarjevih besedah tudi ne verjamejo, da ugajajo bogu, da so v božji milosti; ne verjamejo božjim obljubam. Vera je torej absolutno zaupanje v odnosu do boga in tudi dejanje absolutnega sprejetja, ne samo vprašanje razuma, ampak akt iracionalnega doživetja.

Podrobno se tudi ustavlja pri dojemanju Kristusove večerje med katoliki in protestanti, pri razumevanju vprašanja zakramentov in maševanja. Obsoja sklicevanje na svetnike, malikovanje in »falešno« darovanje.

Tudi v Cerkovni ordningi se ukvarja z grešniki, s tistimi, ki izgubljajo boga zaradi svojih grešnih dejanj. Trdna moralna, etična struktura je del cerkvene in božje strukture in normam so vsi podložni. Ko Trubar govori mladim ljudem (ta gmajn ljudem) na strani 99 zapiše, da pravi verni ne smejo postati:

/.../ kurbarji, malikovalci, ne prešuštniki, ne tatje, ne vbojniki, ne lakomniki, ne sovražniki, ne ki ne donosijo, ne pijanci, ne pošrehi, ne šentavci, ne razbojniki, ne zoperniki, ne nečisti, ne lažniki, ne kezari, ne ti kir v ti pravi veri res loti k inu zmešnjavo delajo, ne goljufi, ne ofertniki, ne samohvalci, ne reznašauci, ne opravljavci, na kriuci, ne, kir staršom niso pokorni, ne nemilosrdni, ne kir nemaju obene lubezni, ne kir ne drže kar obljubijo, ja leti vsi ne bodo tiga kraljevstva inu Erba nebeškega poseli ne prijeli (prav tam: 99).

Cerkovna ordninga je vpeta v zgodovinski kontekst veliko bolj kot Predguvor, v ozadju slutimo zgodovinsko fresko, opredeljeno s socialnimi negotovost- 
mi in večnim strahom pred smrtjo, katere tesnobno atmosfero predstavljivih in nepredstavljivih groženj so vzpodbujale predstave turških vpadov. Peklensko je bilo del zgodovinske resničnosti, niso bile samo imaginarne podobe pekla, kot si jih je bil zmožen predstavljati izobražen, svetovljanski intelektualec v drugi polovici 16. stoletja. V molitvi Kyrielejson ljudje molijo za rešitev pred hudičevo skušnjavo in turško silo.

Vprašanje vere je za Trubarja kljub vsemu in predvsem teološko vprašanje, ki razkriva človekov odnos do boga, njegovo absolutno sprejetje, a tudi odnos posameznika do skupnosti, pripadnosti pravi skupnosti. Trubar poudarja spoznaven in etičen vidik vere, vera je zanj tudi območje resnice, v nadčasovni veri se mu razpira prisotnost časovne dimenzije, pa tudi vpetost individualnega v skupnosti: občutek odgovornosti za sebe in druge. V sistemu danih, apriornih vrednot se tudi pri Trubarji že sluti novodobni individuum, ki se mora sam odločati. Vera pomeni razumevanje in tudi odločitev za prava dejanja, za pravi način življenja. Dvojnost sveta, ki je vedno končno dognanje Trubarjevih miselnih iskanj in ugotovitev, za Trubarja pomeni, da je na drugi strani prave vere falš - neprava vera, nevera. Nevernike opredeljuje z atributi, ki izhajajo iz spoznavnega področja; tako govori o zmedenosti, zmoti, nerazumevanju, laži, drugosti. Napačno življenje, na primer malikovanje, spremlja napačno razumevanje in pa tudi dvom, ki je implicitno prisoten $v$ neveri, napačnem odnosu do boga, ki je, kot pravi Trubar filozofsko, ustvaril vse reči: vidne in nevidne in ki ga lahko dojamemo z notranjimi očmi.

\section{Sklep}

Leta 1550 je Primož Trubar dal natisniti knjižici Catechismus in der windischen Sprach in Abecedarium und der klein Catechismus in der windischen Sprach, v nadaljnjih letih pa je še razširil svojo zastavljeno dejavnost. Z dvema interpretiranima deloma, Predguvorom in Cerkovno Ordningo, se tudi zaključuje prva doba njegovega ustvarjanja in se odpira pot $\mathrm{v}$ razumevanje njegovih nadaljnih besedil. Pri vprašanju vere in boga je Primož Trubar izhajal iz trdnega, absolutnega teološkega prepričanja, $v$ katerem se je opiral na mislece in priznane avtoritete svojega časa. Vera je bila upodobljena kot komunikacija med bogom in vernikom, kot čisto individualni odnos, a je izražala hkrati tudi pripadnost skupnosti. Trubar poudarja tako gnoseološki kot etični vidik vere. Ni bil samo intelektualni dogmatik in mislec, razkriva se tudi kot čustven razmišljevalec $\mathrm{z}$ domišljijo, ki se najbolj sprosti prav v nazornih, napol literarnih podobah zla, s katerimi poskuša prepričati vernike, da ne bi grešili. Posrednik, tretji $\mathrm{v}$ tej komunikacijski verigi med bogom in človekom, je pridigar z retoričnimi sposobnostmi, ki hoče prepričati skupnost bolj ali manj nevednih. Širjenje vere je bilo zanj poslanstvo, čut za skupnost, zato predpostavlja, da je tudi stopnja zavedanja zgodovinske danosti pri pridigarjih najbolj razvita. Prav njegovo metaforično izražanje dokazuje stopnjo Trubarjeve literarne izobraženosti, podobno kot se to izrazi skozi tkanje literanih kodov v tekst in medbesedilnost 
kot delom njegove literarne (teološke) izkušnje. Razlaga Trubarjeve teološke misli ni enostavna: njegova misel se dostikrat giblje $\mathrm{v}$ nasprotjih, zakriva bolj kot odkriva. Na eni strani se srečujemo s strogim razumskim konstruktom in tradicijo krščanskega mita, na drugi strani z iracionalnim, individualnim dojemanjem vere kot razodetjem; na eni strani poudarja vero kot individualno izkušnjo, na drugi odgovornost in vključevanje v skupnost ...

Vera je predvsem absolutna, absolutno pa Trubar dojema $\mathrm{v}$ antagonističnih opozicijah. Metafizični in tudi geografski prostor verske skupnosti je v njegovih miselnih konstrukcijah strogo razdeljen, kar je delno tudi Trubarjev davek času. Vera je filozofija in hkrati ideologija. Je svet božjega in svet peklenskega, prekletosti in možnega zveličanja. Področje nevere je področje greha in nevednosti, pa tudi področje drugega, sovražnika, tu se sprošča Trubarjev zgodovinski aktivizem. Vera tako postaja ne samo moralno, teološko vprašanje, ampak tudi politično. Prav ta zgodovinska dimenzija Trubarjeve vere je na prvi pogled najbolj prepoznavna in dopušča najbolj enosmerne kakor tudi politične interpretacije.

Trubar nikoli ni odpustil nevernikom, vprašanje vere je še kasneje dojemal $\mathrm{v}$ zgodovinskem kontekstu in $\mathrm{v}$ kontekstu prave, protestantske cerkve - nevero in dvom je dojemal na ozemlju drugega, sovražnika, vera mu je pomenila simbolno nesprejetje drugosti, širitev vere je torej doživljal v mesijanski vlogi. V nekaterih odstavkih dela Catehism z dvejma izlagama in v brošuri Ta pervi psalm ̌̌ nega trijemi izlagami (1579) sta druga in tretja izlaga, Explicitio in Allegoria po Koruzi (1983: 31) v bistvu pamfleta na katoliške nasprotnike, čeprav v zunanji obliki cerkvene pesmi.

Dejavnost Primoža Trubarja je bila prav z Ungnadovim biblijskim zavodom vizionarska in politična, skupnost vernikov je poskušal zajeti še širše, kulturni projekt je imel globoke zgodovinske in politične implikacije, skupaj z ostalimi je v preroškem duhu skušal razširiti vero na širše južnoslovansko ozemlje. To njegovo prizadevanje in zgodovinsko razumevanje vere je dopuščalo mnogo interpretacij, tudi političnih, vzpodbujalo je možnost mitiziranja. Prav slovenski znanstvenik Matija Murko, ki je polovico svojega življenje preživel na Češkem, je $\mathrm{v}$ že omenjeni nemško napisani razpravi o slovenski in hrvaški reformaciji in protireformaciji poudaril predvsem pomen Ungnadovega biblijskega zavoda (katerega bistveni člen je bil Primož Trubar) kot prvega južnoslovanskega programa in se je tako navezal na panslovanske ideje in mit o slovanski vzajemnosti, ki jih je $\mathrm{v}$ češkem in slovanskem prostoru pod vplivom Herderjevih idej začel Jan Kollar. V dvajsetih letih 20. stoletja je Matija Murko v čeških člankih ta problem ideologiziral, saj naj bi bil prav Ungnadov biblijski zavod prvi južnoslovanski program kulturne in v ozadju politične združitve vseh južnih Slovanov, predhodnik Kollarjevih idej slovanske vzajemnosti in panslavizma ... 5

\footnotetext{
${ }^{5}$ Že pred leti sem poskušala razkriti, kako je ta prodorni svetovljanski duh in profesor slovanskih literatur nehote zapadel na ozemlje slovanskega mita. Prav on je na začetku z distanco poskušal demitologizirati Kollarjevo idejo slovanske vzajemnosti, v svojih zrelih letih pa je nadaljeval s širjenjem tega mita (Jensterle - Doležal, Alenka, 2005:
} 
Končam naj z mislijo češkega filozofa T. G. Masaryka, ki naj označi tudi prizadevanja Primoža Trubarja: »Ni nam treba duhovne ravnodušnosti, ampak vere, žive vere v nekaj višjega kot smo mi, v nekaj velikega, vznesenega, povzdignjenega in večnega. « In Trubar je to vero imel in jo z vso gorečnostjo, a tudi strpnostjo v slovenskem jeziku večji del svojega življenja iz nemških krajev svojega bolečega izgnanstva poskušal razširjati med Slovence. Politik in mislec $\mathrm{z}$ etično in filozofsko poglobljenostjo, s čutom za drugega in občutkom odgovornosti za skupnost je s svojimi idejami in interpretacijo sveta v okviru teološke miselnosti poskušal osmisliti in spremeniti svet svojega časa. Čeprav je veskozi poudarjal eshatološke vidike vere, se je do globin zavedal zgodovinske resničnosti, predvsem pa odgovornosti do skupnosti; vero je razumel kot moralno kategorijo, vera je bila za Trubarja kot pridigarja in vernika, kot za tistega, ki razume in to razumevanje posreduje naprej, vprašanje resnice, spoznanja, absolutne zavezanosti, predanosti bogu, a tudi konkretnemu človeku, skupnosti. Zgodovinsko in individualno, sveto in grešno, časovno in večno, pulzirajoče v njegovih teoloških interpretacijah, je duhovno obzorje, ki nam ga še danes posreduje Primož Trubar kot »zavezo « tudi za današnji svet, saj je prav on tisti, ki s svojimi teksti še danes vznemirja in vzbuja občutek odgovornosti in izpostavljenosti na poti iskanja resnice, ki jo še vedno lahko poimenujemo kot sveto, božjo izkušnjo.

\section{LITERATURA}

Branko BERČIČ, 1968: Das slowenische Wort in den Drucken des 16. Jahrhunderts. Abhandlung uber die slowenische Reformation (Geschichte, Kultur und Geisteswelt der Slowenen I). Munchen. 152-265.

Vekoslav GRMIČ, 1986: Korenine Trubarjeve teološke misli, Pogorelec, Breda, Koruza, Jože (ur.): 16. stoletje v slovenskem jeziku, književnosti in kulturi. 20. seminar slovenskega jezika, literature in kulture: zbornik predavanj. Ljubljana: Filozofska fakulteta, Oddelek za slovenistiko, Center za slovenščino kot drugi/tuji jezik. 129-139.

France KIDRIČ, 1919: Die protestantische Kirchenordnung der Slovenen im XVI. Jahrhundert. Slavica 1. Heidelberg.

Jože KORUZA, 1983: Protestantismus bei den Slowenien, Protestantizem pri Slovencih. Weiner Slowenischer Almanach. Sonnerabend 13. 15-37.

Matija MURKO, 1927: Die Bedeutung der Reformation und Gegenreformation fur das geistigen Leben der Sudslaven. Prag, Heidelberg.

Mit slovanske vzajemnosti pri Matiji Murku. Pospíšil, Ivo, Zelenka, Miloš (ur.): Matija Murko v myšlenkovém kontextu slavistiky. Brno, Ljubljana: Ústav slavistiky FF MU, Inštitut za slovensko literaturo in literarne vede ZRC SAZU. 136-148). 
Jože POGAČNIK, 1973: Zgodovina slovenskega slovstva. Maribor: Založba Obzorja Maribor.

Rudolf TROFENIK, 1973: Uvod. Cerkovna ordninga 1. Teil. Geschichte, Kultur und Geistwelt der Slowenien. Munchen: Biblioteca Apostolica Vaticana.

Jože RAJHMAN, 1977: Prva slovenska knjiga v luči teoloških, literarno-zgodovinskih, jezikovnih in zgodovinskih raziskav. Ljubljana: Partizanska knjiga.

- -, 1986: Trubarjeva Ena dolga predguvor. Ljubljana: Cankarjeva založba.

Mirko RUPEL, 1962: Primož Trubar, življenje in delo, Ljubljana.

Drago ŠEGA, 1975: Med biblijo in Cerkovno ordningo. Trubar, Primož: Slovenska cerkovna ordninga, Ljubljana: Mladinska knjiga. 113-138.

Zbrana dela Primoža Trubarja I-V, 2002-2006. Krajnc, Vrečko, Francka, Vinkler, Jonatan (ur.), Ljubljana: Rokus.

Jonatan VINKLER, 2006: Slovenska protestantska veroizpoved in cerkveni red za vse dni v letu (k tretji knjigi zbranih del Primoža Tribarja). Grdina, Igor (ur.), Primož Trubar, Študije k zbranim delom I-V. Ljubljana: Rokus. 95-99.

\section{SUMMARY}

In my paper on the concept of faith and doubt in Primož Trubar's works, I have focused mainly on two characteristic texts from his opus: Ena dulga predguvor (Urach, 1557) and Cerkovna ordninga (Tübingen, 1564). The problem of faith is presented in his first book, Katehizem (1550), in which he wrote about faith in his first famous sermon that was to be repeated many times thereafter; he argued that faith is a "gift from God", and it is as hereditary as the Great Sin is. Trubar's spiritual world is theologically and morally strongly divided into good and evil: on the one hand there is the right faith in God, forgiveness of sins, salvation, and the possibility of eternal life; on the other, the Devil's side, is condemned evil, guilt, and sin. In the text Predguvor, the problem of belief does almost not exist, and secret doubt is connected with the (non-)sense of suffering. Faith means understanding, and the decision to perform the right deeds, and to live a Christian life. Trubar's theological thought implies other enemies - Turks, Jews, pagans, and the Pope's Christians. Faith is the problem of the Church and the religious community: it represents the social antagonism of the right and pretentious believers. The Cerkovna ordninga is - compared to Predguvor - even more embedded in its historical context. The question of faith is here equal to the question of human attitudes towards God, the absolute acceptance that implies most of all the relation of an individual towards the community, and belonging to the right community. Trubar always thinks about enemies in his texts, although he tries to understand them; the problem of faith is therefore connected with the decision to belong to the right Protestant Church. 